\title{
Research on the Effectiveness of the Ideological and Political Education for University Students under the Environment of Internet Technology
}

\author{
Jun $\mathrm{Wu}^{1}$, \\ 'Jiangxi University of Traditional Chinese \\ Medicine, \\ Nanchang,Jiangxi,330004 China
}

\author{
Donghua Liao ${ }^{1}$ \\ 1Jiangxi University of Traditional Chinese \\ Medicine, \\ Nanchang,Jiangxi,330004 China
}

\author{
Aimin Chen ${ }^{1, a}$ \\ 'Jiangxi University of Traditional Chinese Medicine, \\ Nanchang,Jiangxi,330004 China \\ ${ }^{a}$ chenaiminjxfz1971@126.com ( ${ }^{*}$ Corresponding Author)
}

\begin{abstract}
In this paper, we conduct survey on ideological and political education for university students under the environment of Internet technology. The Internet brings the effect of ideological and political education is objective, but it is far-reaching, it widely exists in the real world and virtual world as well as the two frictions and fit in. The ideological and political education have a broad horizon also encountered the difficulty of administration. With the combination of Internet, we could largely promote and enhance the current pattern of ideological and political education.
\end{abstract}

Keywords: Ideological and Political Education; University Students; Internet Technology.

\section{Introduction}

Derived the revolutionary technology of the Internet as well as the related including post-modern, renew ideas, directly or indirectly, breaks the traditional mode of ideological and political education, especially the Internet broke the traditional ideological and political education of the border, the border of both the education and the education. The Internet as a kind of modernity, although its development time is not long, but it has implemented and can foresee a huge potential to multidimensional tentacles extend to all aspects of human society and is closely related to our living conditions and education, it has become the people see the influence of objective existence. Environmental changes brought about by the Internet make the ideological and political education is faced with involves huge impact on the level of technology and ideas, how to understand fully, build, and make good use of the new environment, is the decisive factor of contemporary ideological and political education success or failure. First of all, as the computer concept of the Internet is a group of single link between the technology, while the range of the flow of information through this link from one machine to machine, which is the basis of the Internet is also the most familiar meanings, namely the technical carrier, as some scholars on "under the Internet environment, the network carrier will become the mainstream of scientific information communication carrier, scientific information communication process will greatly simplify and enrichment, information interaction between waiters and recipients will be greatly increased because of this, the characteristics of the Internet, with its fast and large amount of information thoroughly subverting the traditional carrier. The Internet as the environmental impact of ideological and political education is based on its connotation extending from biology to technology and linguistics which is to grasp the complexity and difficulty in the Internet environment but on the other hand it was also an 
overview of the starting point and the breakthrough point of the Internet [1-3].

The Internet brings the effect of ideological and political education is objective, but it is far-reaching, it widely exists in the real world and virtual world as well as the two frictions and fit in. Overall, environmental changes brought about by the Internet including technical series of traditional education was broken on the border, especially the combination of postmodernism and Internet stir up the arrival of the era of ideological collision, dialogue is unexpected. Internet in technology brings great change in the surface layer is caused the teaching environment of virtualization, realized the simulation of teaching lifelike and true and the teaching content of digitization which changed the traditional books rigidity: or even been involved in the management of network [3-5]. But, in fact, the Internet's influence on the ideological and political education which is that it's degrading to break the traditional education myth, dispelling the traditional education model, breaking the traditional boundary. A general sense of traditional education was strictly limited in school education and education and the education is strictly separated, but the virtual and the real society is neck and neck dispelling the boundary, which on the one hand manifests in the virtual community education undifferentiated, namely the network in the virtual community life is intertwined with network education, also can saying is the network education appear invisible, namely Internet without education, but everywhere on the network and education; On the other hand is a variety of professional education website broke through the traditional single education limit, has realized the network learners, flow line and informality: the diversity of space between different web sites links and the links between different fields of the same site. So the ideological and political education have a broad horizon also encountered the difficulty of administration.
In this paper, through literature review and survey, we conduct research on the ideological and political education for university students under the environment of Internet technology. The advent of the era of the Internet also herald a new era of dialogue. In the traditional sense of the education association is only limited on the level of "alone". This includes education teaching and the teaching between the recipients of the authority, pure text form of teaching material to write on. The detailed research and discussion will be introduced in the following sections.

\section{The Principles of Our Research}

The Development of Ideological and Political Education. Contemporary college students' ideological and political education is the complex system engineering, and is of great significance must be effective in the process. Significant ideological and political education meaning, makes the most rational path must seek the optimal and maximize the effect of ideological and political education. Under the perspective of scientific development concept, must be clear the value of ideological and political education, to explore the basic requirement of the contemporary college students' ideological and political education. Only then, can further grasp the question essence, effectively improve the actual effect of ideological and political education. Zeitgeist is with the spirit of the theme of the specific era, is the subject of the specific time in people's ideology. It deeply reflects the style of that particular era, the main task, the idea of people. At any one time life of the state, society, or the general public, only grasping the theme of times and the spirit of The Times in order to better adapt to the changes of The Times, to solve the specific the theme of The Times, on this basis to achieve greater progress, social and historical practice to have a better development of the country, society and the individual itself. The scientific outlook on development under the 
perspective of ideological and political education in the value of the appeal is important. During the period of German classical philosophy, Kant put forward "is purpose, rather than a means". Psychologist in the person's potential and value also emphasizes the importance of human being itself, emphasize the value of everyone has own existence, no development potential. Education, Rogers proposed should be "people-centered" and "student-centered". The value of these concepts emphasizes respect for people, respect people's initiative and creativity, the significance of initiative. Marx also on many occasions stressed the importance of human being itself, insisted that the person is not a fixed chain link, also is not a nail on a fixed position, more is not created by the slaves, people should have the most comprehensive nature, emphasizes healthy society is should respect people's value, highlights the value of a man. The scientific outlook on development under the perspective of ideological and political education ultimate goal is to promote the development of the overall progress of college students and the real. Specifically, is to change rule, understanding to university students, on the basis of the reality for college students psychological demand, future ideal goal, understanding, on the basis of the characteristics of the current era and society overall situation understanding, on the basis of overall consideration, design concept, overall train of thought and planning work in the specific implementation in reality to promote students' real progress and real development of individuals, is to ensure students' future development and progress, can truly is to be on the level of yuan theory to guide practice, to promote the development of college students' scientific quality. In essence, the ideological and political education, the problems in the development of students' lack of rational, clear understanding, there is a moment of enthusiasm, reckless development, but for how to promote students' development is based on a lack of comprehensive understanding of patient and rational.

\section{The Challenge of Internet Environment} and Media Technique. Information can maximize the socialization of ideological and political education work. Ideological and political work information can be linked to government agencies, family, school, it provides the social from all walks of life to participate in the ideological and political education work is convenient, and can realize the ideological and political education work in the family and the combination of social forces. Make the ideological and political education work harder and which helps to further develop the advantage of ideological and political work. Information resources sharing make ideological and political education can possess in the information market and information to people through ideological education, which in a certain sense overcome the shortcoming of the traditional ideological and political work, however small. At the same time the information has the precious characteristics of visualization, interesting, can make it more attractive. In addition, information resources can make the ideological and political work with sex workers from the Internet to know people's real thought tendency, targeted correct ideas release information on the Internet to education guide people and to establish the idea of a good style of work, ideal and faith. Mobile media close sex, real-time and interactive features to make the university campus information communication presents "of time, space and information barrier-free" state. Students can absorb any information they need at any time with mobile phone network. This means that in the media age, the influence of network on college students' group to further strengthen. Profoundly affects the college students' ideological and political education. The way of how to use the network innovation ideological education, firmly grasp the ideological and political education initiative, should become the realistic problem of educators must think. In the traditional education mode, educators through precipitation accumulated knowledge and experience. Not only in theory 
but also in the knowledge reserve has more superiority in words. They may, according to the needs of classroom education, handy to social and political dynamic aspects such as economy, politics and reserve knowledge at random and necessary education content conformity, with rich and vivid content and language to strengthen education persuasive and attractive. Since the media is widely application in college students groups and extension the present ideological and political education teachers possession of education information resources.

Weibo as an open, interactivity and optional the gender is strong network communication platform, it broke the reality of subject and object in the process of education asked in psychological boundaries in real life, education can through the microblogging to equality between the two sides free to express their ideas, comments and opinions. Students can freely on media confide heart, emotion, seeking help, as a teacher, can consciously published such as life feeling, two death experience, social commentary with a more equal and harmonious state in dialogue with students. Using Internet communication, in virtually dissolved the isolation between teachers and students reduced the opposite state in real life and the theory of ideological and political education empty stiff lectures less, easier to let the students to accept.

The Combination of Internet with Ideological and Political Education. In the present economic and technological conditions, the Internet is the main part of the new media the development of mobile media is more quickly. New media in addition to the web, and mobile, including digital television, live satellite TV, mobile TV, interactive network television, network television, building video, outdoor large screen, warm catalyst, instant communication, virtual communities, blogs, podcasts, search engines, simple aggregation, etc. Its role in the new media presents diversity, interactive, personalized, virtual, etc. In the face of new challenges, we should carefully study the new media era new laws and new characteristics of ideological and political education which realize the modernization of ideological and political education. The spread of new media is a huge amount of information platform, students can choose according to their own interests and hobbies to information, and not limited by time and space. At the same time, the college student is not only the information of the receiver and is free to participate in production and transmission of information, the information output. In traditional ideological and political education, the education object state of mind and the new media age compared with high homogeneity, and so on the design of the content of education has the characteristics of simplicity, and that already could not adapt to the needs of the new media age diversity of college students' thought condition. In addition, the traditional ideological and political education failed to timely according to the virtual space to design new psychological problems in targeted education content, simply use the traditional education to college students' ideological and political education content. All kinds of performance is the traditional ideological and political education content is lack of pertinence in the era of new media, as an educator, should keep pace with the times, in a timely manner according to the new media era of college students' thought condition adjustment education content in order to improve the effectiveness of education. In the following figure one, we use the graph to illustrate the steps and procedure of combining Internet with education. 


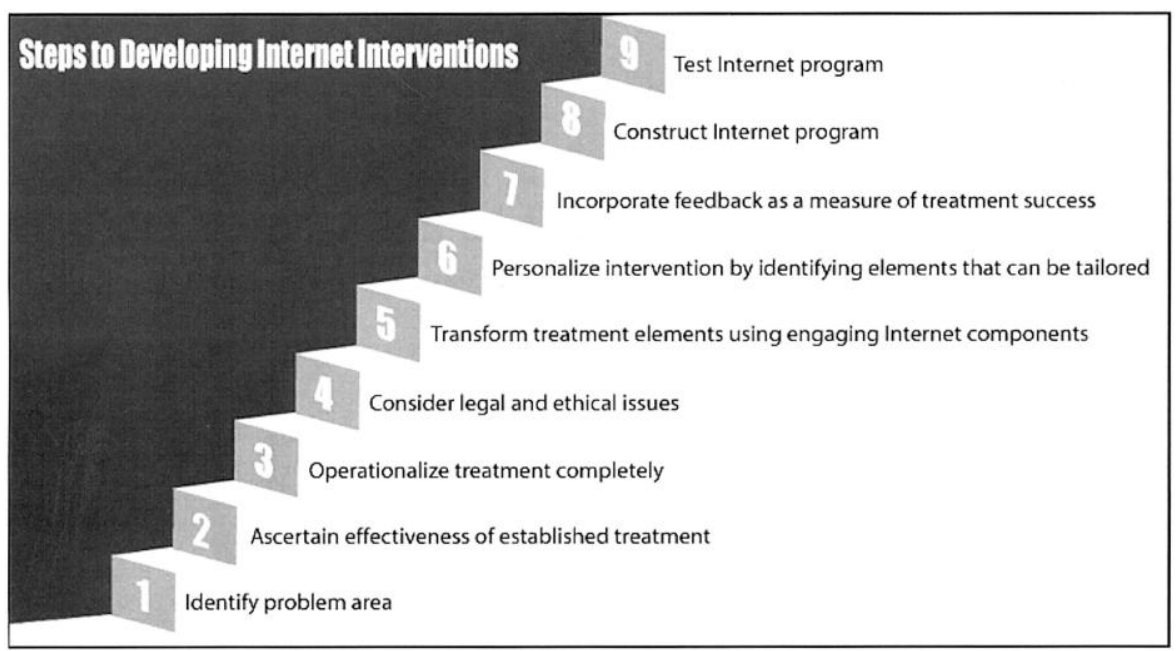

Fig 1. The Steps and Procedure of Combining Internet with Education

\section{Conclusion}

In this paper, we conduct survey on ideological and political education for university students under the environment of Internet technology. The Internet as a kind of modernity, although its development time is not long, but it has implemented and can foresee a huge potential to multidimensional tentacles extend to all aspects of human society and is closely related to our living conditions and education, it has become the people see the influence of objective existence. The combination will promote and enhance the performance of the current education pattern.

\section{References}

[1] Heliang, L. (2014). On the philosophical conception of the value of ideological and political education. Teaching \& Research.

[2] Yuting, L., \& Li, G. (2014). Spiritual communication:the essence of ideological and political education interaction. Teaching \& Research.

[3] Ji, Q., \& Xue, M. (2014). A historical study of the goal of cpc ideological and political education. Teaching \& Research.

[4] Jun-qi, W., \& Zhen-jun, Z. (2014). On incorporating psychology into university ideological and political education. Journal of Bingtuan Education Institute.

[5] Zhong, M., Shuanggen, L., Marxism, S. O., \& University, L. (2014). Research status of language on the ideological and political education and its perspectiveness. Journal of Jiangxi Normal University. 